\title{
Internet Addiction: Relationship with Perceived Freedom in Leisure, Perception of Boredom and Sensation Seeking
}

\author{
Feyza Meryem Kara ${ }^{1}$ \\ ${ }^{1}$ Faculty of Sport Sciences, Kırıkkale University, Kırıkkale, Turkey \\ Correspondence: Feyza Meryem Kara, Faculty of Sport Sciences, Kırıkale University, Kırıkale, Turkey. E-mail: \\ feyzameryemkara@gmail.com
}

Received: March 14, 2019

Accepted: March 29, 2019 Online Published: April 26, 2019

doi:10.5539/hes.v9n2p131

URL: https://doi.org/10.5539/hes.v9n2p131

\begin{abstract}
This study aimed to examine the university student's internet addiction, perceived freedom in leisure, leisure boredom, and sensation seeking level with regard to gender and physical activity participation, and to investigate the relationship between internet addiction, perceived freedom in leisure, leisure boredom and sensation seeking. The participants who were chosen using a convenience sampling method filled the "Short Form of Young's Internet Addiction Test" (YIAT-SF), Perceived Freedom in Leisure Scale (PFLS), "Leisure Boredom Scale (LBS), and "Sensation Seeking Scale" (SSS). T-test, MANOVA, ANOVA and correlation analysis were used to analyze the data. T-test results indicated there were no significant differences in the mean scores of "YIAT-SF" with respect to gender ( $p>0.05$ ). However, analysis revealed significant differences in the mean scores of "YIAT-SF" with regard to not regularly physical activity participation. There were significant differences in the mean scores of "PFLS" in favor of men participants and regularly physical activity participants $(p<0.05)$. Gender and regularly physical activity participation were significant of "LBS" $(\mathrm{p}<0.01)$ in favor of women participants $(p<0.05)$. Similarly, gender were significant of "SSS" $(p<0.01)$ on the all sub-dimensions in favor of men participants $(\mathrm{p}<0.05)$. However, there were no significant differences in the mean scores of regularly physical activity participation.
\end{abstract}

Keywords: internet addiction, perceived freedom, leisure boredom, sensation seeking

\section{Introduction}

In recent years, all kinds of addiction from the use of a substance to use of obsessive technology are considered as the subjects that need to be focused and dealt with (Kang, Park, Park \& Park, 2012). For this reason, it's been observed that psychological and physiological mechanisms underlying the addiction have been investigated by different disciplines and theoretical frameworks (Hawi \& Samaha, 2018; Mazzoni, Cannata, \& Baiocco, 2017). Considering all this information, the researchers focus on what are the personal perceptions of individuals within their leisure time and what are the psychological variables that lead to addiction/dependence on individuals.

\subsection{Internet Addiction}

With each passing day, use of the Internet became increasingly widespread as a popular leisure time activity (Dang et al., 2018; Kuss \& Griffiths, 2011) the concept of addiction is often used side-by-sides (Frangos et al., 2010; Kang et al., 2012). At this point, although there is no diagnosis of internet addiction, it is generally defined as being overly frustrated and aggressive when being deprived of internet use (Arısoy, 2009).

Internet addiction's research of stated that the population, especially was born between the years 1995-2012, called the "Z generation", is closer and more prone to the internet world (Geck, 2007). In Germany, 3.7\% of the regular users (2.1\% of the total German population) has been detected as addicted (Müller, Glaesmer, Brähler, Woelfling \& Beutel, 2014). According to a study conducted in the United States, around $26.3 \%$ of university students have been reported to be an internet addict (Moreno et al., 2011). Similarly, in another study of university students in Egypt, the rate of internet addiction has been identified as $40 \%$ (Al-Gamal, Alzayyat \& Ahmad, 2016). According to a study conducted in Turkey in 2017, approximately $1.6 \%$ of the students participating in the study were internet addicts and $16.2 \%$ were identified as potential internet addicts (Seyrek, Cop, Sinir, Ugurlu, \& Şenel, 2017).

Considering these researches, it can be said that the debates between the advantages and disadvantages of 
internet using is continue. At this point, the advantages and disadvantages according to the purpose of Internet use are emerging (Blais, Craig, Pepler \& Connolly, 2008) young population's being an Internet user in a wide spectrum ranging from entertainment to educational objectives (Al Otaibi, 2012) changes these results. For example, the research shows that young people use the internet not only for surfing but also for societal relations with using sites like facebook (Andreassen, Pallesen, \& Griffiths, 2017; Junco, 2012; Phanasathit, Manwong, Hanprathet, Khumsri, \& Yingyeun, 2015; Wang, Ho, Chan, \& Tse, 2015). At this point, it can be said that social networking sites have an important potential to facilitate social relations.

In addition, it is stated as a separate evaluation in many surveys that the tendency of internet addiction increases day by day and the socialization tendencies of individuals are gradually decreasing (Whang, Lee, \& Chang, 2003). As mentioned in many research studies on Internet use, the relationship between computer game addiction and psychosocial variables (such as increasing loneliness, decreasing of life satisfaction and reduced social competence) is reported to cause an increase of social and emotional problems (Ko, Yen, Yen, Chen \& Chen, 2012). Undoubtfully leisure time has been being studied in different categories depending on the activities performed. It is considered as the output of an experience that occurs during any activity, depending on emotions and perceptions (Ellis \& Witt, 1994).

\subsection{Perceived Freedom in Leisure}

Perceived freedom is considered to be the case in which the person wants to do/does according to their choice and request (Neulinger, 1981). In addition to this, people who live highly perceived freedom in their leisure are feel competent. They perceive that they are able to control leisure before participation, during accession and after accession in the activity. On the other hand, it is believed that the obstacles or restrictions such as insufficient resources, transport, money and time, reduce the perceived freedom in their leisure (Ellis \& Witt, 1994) Individuals with low perceived freedom in their free time experience a sense of desperation in their free time and rely on opportunities provided by others (Ellis \& Witt, 1994). Iso-Ahola (1980) stated that the two conditions of influential leisure are the perception of freedom and intrinsic motivation. He also stated that the most important point was perceived freedom. Additionally, Csikszentmihalyi (1975) has examined the flow of consciousness in Flow Theory. Within the consciousness changes of individuals, the functional components of leisure are focused on both depth and emotional involvement.

\subsection{Leisure Boredom}

Based on the following points, it is seen that researchers' one of the most interested working subjects in recent years is, "leisure boredom" (Spruyt, Vandenbossche, Keppens, Siongers \& Van Droogenbroeck, 2018; Wang, 2018). Although academic interest in the concept of leisure boredom extends to the early 1900s, it appears to be a relatively less examined emotion or a neglected concept (Vodanovich \& Watt, 2016). According to Iso-Ahola \& Weissinger (1990), leisure behavior is optimally arousing for it to be psychologically rewarding, especially when individuals perceive that they have just the right amount of time for leisure activities; not too much or too little. Csikszentmihalyi (1975) has sought to clarify the concept of leisure boredom with flow theory and has defined it as a special experience related to both activity and environmental factors. The individual is fully involved (included) and interested in the activity or leisure process in which he is engaged in the perception of flow. Otherwise, if there is no "flow", the individual feels bored or anxious. And at this point, individuals are mentally unable to reconfigure their time while experiencing boredom (Barnett \& Klitzing, 2006). Researches show that about $10 \%$ of the young population are often bored in their leisure time (Haller, Hadler \& Kaup, 2012). Chou, Condron \& Belland (2005) stated that Internet addiction is explained by the problem of time management. Similarly, Hill and Perkins (1985) stated that the leisure boredom consequence of conflicting perceptions of having too much time available with too little to do. Therefore, the perception of boredom can be said to be closely related to internet addiction. (Li, O'Brien, Snyder \& Howard, 2015; Skues, Williams, Oldmeadow \& Wise, 2016).

\subsection{Sensation Seeking}

One of the issues that need attention to internet addiction can also be considered as sensation seeking. In the literature, studies on sensation seeking and Internet addiction were mostly conducted with university students (Dalbudak et al., 2015; Jang, Sohn, \& Yu, 2018). Sensation seeking theory first performed by Martin Zuckerman in 1979, is associated with the individual's bravery or research motivation in new stimuli in generally unfamiliar situations Zuckerman (1994), described sensation seeking as a variety of new, diverse, complex and high levels of excitement to seek and experience, but also to face up to the economic, physical, societal, legimate and risks for the sake of these experiences. This theory claims that individuals have different impulse levels and excitement needs. At this point, the concept of intensity stands out in this theory. For the intensity to be an 
intrinsic reward, an individual must be seeking a high level of excitement (Zuckerman, 2007: 48-49). Therefore, it can be said that the actions that contain risk are in parallelization with the behavior of sensation seeking. The theory of sensation seeking is divided into two, personal attributes and situational attributes. In personal attributes, it is stated that individuals seeking a high level of excitement for a new situation are likely to have less risk perception trends. Situational attributes are expressed as where the individual is experiencing positive senses and satisfying when facing an unfamiliar situation (Zuckerman, 1996: 125-129) sensation seeking levels show some changes in Individuals with different levels of arousal. Those levels constitute the extent of the sensation-seeking behavior and they are grouped as search for thrill and adventure Seeking (a desire to make exciting extraordinary events with speed and danger-related behavior), experience seeking (anew, different and an unorthodox lifestyle), disinhibition (the need to engage in social activities, parties or sex-related activities by consumption of alcoholic or similar substances) and boredom susceptibility (not liking repetition, routines and boring activities or monotonous and dull people). According to Lavin, Marvin, Mclarney, Nola \& Scott (1999), there is a non-positive relationship between with sensation/adventure/excitement seeking and Internet addiction.

Given that internet use is an inevitable global trend; excessive Internet use is an issue that must be taken into consideration in many countries. It is believed that the resolution of young people's risky behavior can be enlightened by researching the dimensions of the perception of leisure boredom, sensation seeking and perceived freedom in leisure. Within this importance, this study aimed to examine the university student's internet addiction, perceived freedom in leisure, leisure boredom, and sensation seeking level with regard to some variables, and to investigate the relationship between internet addiction, perceived freedom in leisure, leisure boredom and sensation seeking.

\section{Method}

\subsection{Study Group}

The participants were 397 university students (234 females and 163 males) from Kırıkkale/Turkey. Participants ranged in age from 16 to 23 years ( $M_{\text {agefemale: }} 19.73 \pm 1.14$; $\left.M_{\text {agemale: }}: 20.20 \pm 1.41\right)$.

\subsection{Data Collection Tool}

Young's Internet Addiction Test-Short Form (YIAT-SF): The scale, developed by Young (1998) and changed into a short form by Pawlikowski, Altstötter-Gleich, and Brand (2013), was adapted into Turkish by Kutlu, Savc1, Demir \& Aysan (2016). High scores from the scale indicate high internet addiction. The scale consists of 12 items and has a 5-point Likert-type design. In this study, internal consistency coefficient for scale was found as .92

Perceived Freedom in Leisure Scale (PFLS): The scale developed by Ellis and Witt (1984) and was adapted into Turkish Yerlisu Lapa and Agyar (2017). High scores obtained from the scale indicate high levels of perceived freedom in leisure. Participants responded to items on a 5-point Likert Scale. In this study, internal consistency coefficient for scale was found as .89 .

Leisure Boredom Scale (LBS): The scale was developed by Iso-Ahola and Weissinger (1990) was adapted into Turkish by Kara, Gürbüz and Öncü (2014). The scale consists of 10 items and has a 5-point Likert-type design. The Leisure Boredom Scale consists of two subscales (boredom and satisfaction). In this study, internal consistency coefficient for scale was found boredom as .89, for satisfaction as .77.

The Sensation Seeking Scale (SSS) Form; The scale was developed by Zuckerman, Eysenck \& Eysenck (1978) was adapted into Turkish by Öngen (2007). The scale consists of 40 items and has a 5-point Likert-type design. Scale consists of four subscales (thrill and adventure seeking "TA", experience seeking "ES", disinhibition "DS", and boredom susceptibility "BS"). In this study, internal consistency coefficient for TA (.81), ES (.79) DS (.77) and BS (.82.) was calculate.

\subsection{Analysis of Data}

The participants were informed about the confidentiality of personal information during the data collection process. University students were informed that completion of the inventory was voluntary. collected data were analyzed with SPSS 23.00. T-test MANOVA, ANOVA and Correlation Analysis were used in this study. Additionally, students t-test and MANOVA was used to determine internet addiction, perceived freedom in leisure, leisure boredom, sensation seeking according to gender and physical activity participation. Correlation Analysis was used to investigate the relationship between internet addiction, perceived freedom in leisure, leisure boredom and sensation seeking of the university students. 


\section{Results}

According to t-test results, it was determined that the average points of participants did not vary $(\mathrm{p}>0.05)$ in YIAT-SF $\left(\mathrm{t}_{(397)}=0.906 ; \mathrm{p}>0.05\right)$ with regard to their genders (Table 1).

However, it was determined that the average points of participants in PFLS varied with regard to the gender variable $\left(\mathrm{t}_{(397)}=-4.298 ; \mathrm{p}<0.05\right)$. The average points of male participants were determined to be higher than the average points of female participants (Table 1).

The MANOVA results determined that the basic effect of the gender variable in LBS was significant $(\mathrm{p}<0.01)$ (Hotellings: $0.00, \mathrm{~F}_{(1.395)}=8.107, \mathrm{p}<0.01$ ). According to the multiple variance analysis, it was seen that the boredom perception of individuals who participated in the research in leisure time varied in "boredom" sub-dimension $\left(\mathrm{F}_{(1.395)}=1.665 ; \mathrm{p}<0.05\right)$. When the boredom sub-dimension was evaluated, a significant difference in favor of female participants was determined (Table 1).

The MANOVA results determined that the basic effect of the gender variable was significant $(\mathrm{p}<0.01)$ in all sub-dimensions of the SSS (Hotellings: 0.00, $\mathrm{F}_{(1.395)}=7.383$, $\mathrm{p}<0.01$ ). According to the multiple variance analysis, the gender variable varied in sub-dimensions of thrill and adventure seeking $\left(F_{(1.395)}=2.775 ; p<0.05\right)$, experience seeking $\left(\mathrm{F}_{(1.395)}=.343 ; \mathrm{p}<0.05\right)$, disinhibition $\left(\mathrm{F}_{(1.395)}=3.146 ; \mathrm{p}<0.05\right)$, and boredom susceptibility $\left(\mathrm{F}_{(1.395)}=3.614\right.$; $\mathrm{p}<0.05$ ). In all sub-dimensions, the results were in favor of male participants (Table 1).

Table 1. T-test (YİA-SF) (PFLS) and MANOVA (LBS) (SSS-V) Results According to Gender

\begin{tabular}{|c|c|c|c|c|c|c|}
\hline & & & $\mathbf{N}$ & $\mathbf{X}$ & Sd. & p \\
\hline \multirow{2}{*}{ Internet Addiction } & & Women & 234 & 3.86 & .28 & .365 \\
\hline & & Men & 163 & 3.83 & .29 & \\
\hline \multirow[t]{2}{*}{ Perceived Freedom } & & Women & 234 & 3.72 & .28 & .000 \\
\hline & & Men & 163 & 3.85 & .31 & \\
\hline \multirow[t]{4}{*}{ Leisure Boredom } & Boredom & Women & 234 & 3.77 & .28 & .001 \\
\hline & & Men & 163 & 3.67 & .33 & \\
\hline & Satisfaction & Women & 234 & 2.36 & .34 & .198 \\
\hline & & Men & 163 & 2.32 & .29 & \\
\hline \multirow[t]{8}{*}{ Sensation Seeking } & Thrill and Adventure Seeking & Women & 234 & 1.43 & .17 & .002 \\
\hline & & Men & 163 & 1.44 & .20 & \\
\hline & Experience Seeking & Women & 234 & 1.41 & .14 & .000 \\
\hline & & Men & 163 & 1.42 & .13 & \\
\hline & Disinhibition & Women & 234 & 1.31 & .25 & .024 \\
\hline & & Men & 163 & 1.39 & .25 & \\
\hline & Boredom Susceptibility & Women & 234 & 1.43 & .21 & .010 \\
\hline & & Men & 163 & 1.47 & .17 & \\
\hline
\end{tabular}

According to $t$-test results, the average points of participants in $\operatorname{YIAT}-\operatorname{SF}\left(\mathrm{t}_{(397)}=0.906 ; \mathrm{p}<0.05\right)$ varied significantly according to the participation in physical activity variable. The average points of internet addiction of the participants who stated that they do not regularly participate in the physical activities were determined to be higher than those who participate regularly (Table 2).

However, it was determined that the average points of participants in PFLS significantly varied according to the participation in physical activity variable $\left(\mathrm{t}_{(397)}=4.283 ; \mathrm{p}<0.05\right)$. According to the findings, a significant difference was found in favor of participants who participate in physical activity (Table 2).

The MANOVA results showed that the basic effect of the participation in physical activity variable in LBS was significant $\left(\mathrm{p}<0.01\right.$ ) (Hotellings: $\left.\left.0.00, \mathrm{~F}_{(1.395}\right)=5.770, \mathrm{p}<0.01\right)$. According to the multiple variance analysis, the boredom perception of individuals who participated in the research in leisure time varied in satisfaction sub-dimension $\mathrm{F}_{(1.395)}=3.127$; $\left.\mathrm{p}<0.05\right)$. When the satisfaction was evaluated, a significant difference in favor of participants who participate in physical activity was determined (Table 2).

According to the MANOVA results, the basic effect of the participation in physical activity variable was

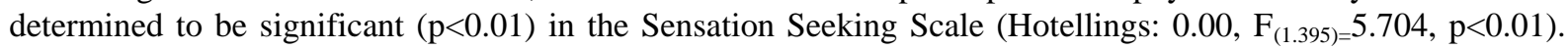
Besides, according to the multiple variance analysis, the participation in physical activity variable did not vary in sub-dimensions of thrill and adventure seeking $\left.\left(\mathrm{F}_{(1,395)}\right)=1344 ; \mathrm{p}>0.05\right)$, experience seeking $\left(\mathrm{F}_{(1.395)=5.844 ; \mathrm{p}>}\right.$

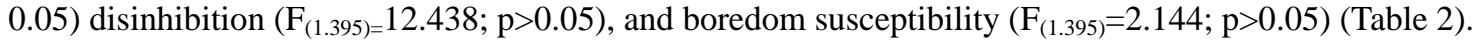


Table 2. T-Test (YİA-SF) (PFLS) and MANOVA (LBS) (SSS-V) Results According to Physical Activity Participation

\begin{tabular}{lllllll}
\hline & & & $\mathbf{N}$ & $\mathbf{X}$ & Sd. & $\mathbf{p}$ \\
\hline Internet Addiction & & Yes & 98 & 3.77 & .29 & .003 \\
& & No & 299 & 3.87 & .28 & \\
\hline Perceived Freedom & & Yes & 98 & 3.88 & .33 & .000 \\
& & No & 299 & 3.73 & .28 & \\
\hline Leisure Boredom & \multirow{2}{*}{ Boredom } & Yes & 98 & 3.69 & .26 & .142 \\
& & No & 299 & 3.74 & .32 & \\
& \multirow{2}{*}{ Satisfaction } & Yes & 98 & 2.37 & .36 & .011 \\
& & No & 299 & 2.27 & .31 & \\
\hline \multirow{2}{*}{ Sensation Seeking } & Thrill and Adventure Seeking & Yes & 98 & 1.41 & .18 & .119 \\
& & No & 299 & 1.44 & .19 & \\
& \multirow{2}{*}{ Experience Seeking } & Yes & 98 & 1.42 & .17 & .466 \\
& & No & 299 & 1.41 & .13 & \\
& \multirow{2}{*}{ Disinhibition } & Yes & 98 & 1.30 & .22 & .050 \\
& & No & 299 & 1.36 & .26 & \\
& \multirow{2}{*}{ Boredom Susceptibility } & Yes & 98 & 1.47 & .17 & .085 \\
& & No & 299 & 1.43 & .20 & \\
\hline
\end{tabular}

As a result of correlation analysis, slightly negative and significant relationships were observed between the internet addiction and PFLS $(r=-.191 ; \mathrm{p}<0.05)$ and SSS in the boredom susceptibility $(r=-.221 ; \mathrm{p}<0.05)$. Slightly negative and significant relationships were observed between the boredom sub-dimension and satisfaction sub-dimension $(r=-.265 ; p<0.05)$ and the experience seeking sub-dimension $(r=-.200 ; p<0.05)$ of Leisure Boredom Scale. Likewise, slightly negative and significant relationships were determined between the satisfaction sub-dimension, disinhibition sub-dimension $(\mathrm{r}=-.158 ; \mathrm{p}<0.05)$ and tendency to boredom sub-dimension $(\mathrm{r}=-.132 ; \mathrm{p}<0.05)$ of Leisure Boredom Scale. A positive and significant relationship was observed between the sensation and adventure seeking sub-dimension $(r=-.124 ; p<0.05)$ and the disinhibition sub-dimension. Lastly, according to the results of the correlation analysis, a slightly positive and significant relationship was determined between the experience seeking sub-dimension and the tendency to boredom sub-dimension $(r=-.142 ; \mathrm{p}<0.05)$.

Table 3. Correlation Coefficients Between Internet Addiction, Perceived Freedom in Leisure, Leisure Boredom and Sensation Seeking

\begin{tabular}{|c|c|c|c|c|c|c|c|c|}
\hline & $\begin{array}{l}\text { Internet } \\
\text { Addiction }\end{array}$ & $\begin{array}{l}\text { Perceived } \\
\text { Freedom }\end{array}$ & Boredom & Satisfaction & $\begin{array}{l}\text { Thrill and } \\
\text { Adventure } \\
\text { Seeking }\end{array}$ & $\begin{array}{l}\text { Experience } \\
\text { Seeking }\end{array}$ & Disinhibition & $\begin{array}{l}\text { Boredom } \\
\text { Susceptibility }\end{array}$ \\
\hline Internet Addiction & 1 & & & & & & & \\
\hline $\begin{array}{l}\text { Perceived } \\
\text { Freedom }\end{array}$ & $-.191 * *$ & 1 & & & & & & \\
\hline Boredom & -.007 & -.010 & 1 & & & & & \\
\hline Satisfaction & .047 & -.047 & $-.265 * *$ & 1 & & & & \\
\hline $\begin{array}{l}\text { Thrill and } \\
\text { Adventure Seeking }\end{array}$ & .072 & -.073 & .076 & .002 & 1 & & & \\
\hline $\begin{array}{l}\text { Experience } \\
\text { Seeking }\end{array}$ & -.079 & .021 & $-.200 * *$ & .067 & .030 & 1 & & \\
\hline Disinhibition & .029 & -.068 & -.051 & $-.158 * *$ & $.124 *$ & .030 & 1 & \\
\hline $\begin{array}{l}\text { Boredom } \\
\text { Susceptibility }\end{array}$ & $-.221 * *$ & -.082 & -.050 & $-.132 * *$ & .085 & $.142 * *$ & .082 & 1 \\
\hline
\end{tabular}

$* \mathrm{p}<0.05 ; * * \mathrm{p}<0.01$

\section{Discussion}

This study aimed to examine the university student's internet addiction, perceived freedom in leisure, leisure 
boredom, and sensation seeking level with regard to gender and physical activity participation and to investigate the relationship between internet addiction, perceived freedom in leisure, leisure boredom and sensation seeking.

According to the findings, it was determined that the average points of participants in YIAT-SF no statistically significant difference according to the gender variable but statistically significant difference according to the participation in physical activity variable. According to the findings, significant findings were found in Internet addiction in favor of participants who did not regularly participate in physical activity. It is not possible to find conclusive results in intersexual comparisons on Internet addiction. There are studies in which gender differences were not found (Mo, Chan, Chan \& Lau, 2018; Stavropoulos et al., 2018) or in which findings in favor of male participants were observed (Li et al., 2015). For example, it was reported by Li et al. (2015) that the male participant's use of virtual gambling, virtual games, and virtual pornography was higher; thus, Internet addiction in men are seen more than women. In another study, it was expressed that Internet use via mobile phones is seen in women more than men (Carbonell, 2012). Beyond the intersexual comparison, it is stated in many studies that Internet activities are more appealing than participation in physical activities for young population (Dang et al., 2018; Hawi \& Samaha, 2017; Khan, 2017). In this context, according to a study conducted in New Zealand in 2016, participation in physical activities decreased due to the rapidly advancing technology (Warbrick, 2016). Within the framework of the findings, the relationship between decreasing physical activity and Internet addiction is observed. However, physical activities were pointed out as an important point in socialization in many studies (Pellegrini \& Smith, 1998; Sherill, 1998).

However, it was determined that the average points of participants in PFLS statistically significant difference according to the gender variable and the participation in physical activity variable. Significant differences in favor of male participant sample who regularly participate in physical activity. As it was stated in the study of Ağyar (2013), women's domestic roles and social tasks have always been a step further than other fields of life in the Turkish population. As an extension of patriarchal society, leisure time obstacles emerge due to reasons such as child and spouse care (Koca, 2016). The fact that university students who took part in the study group are living in a city called "rural" reinforces this discourse. However, all of the students in the study group were single, living in state dormitories, and away from their family. Despite this, freedom perceptions of female university students in their leisure time are still seen lower than the male participants. In this context, the existence of the hegemonic system is thought to be manifested in this environment.

According to the analysis results within the framework of Boredom Perception in Leisure Time significant results in favor of women were determined in the boredom sub-dimension and significant results in favor of those who participate in physical activity were determined in the participation in physical activity sub-dimension. In the related literature, there are studies in which gender differences were not observed (Kara, Gürbüz \& Sarol, 2018a; Kara, Gürbüz, Küçük-Kılıç \& Öncü, 2018b) within the framework of boredom perception as well as many studies in which gender differences in favor of males were determined (Kara et al., 2014; Leung, 2007). In addition to the boredom perception in leisure time and gender relationships, the role of physical activity is especially emphasized in coping with boredom perception in the studies performed in recent years (Deal, 2005; Sommers \& Vodanovich, 2000). At this point, the findings provide parallel results with a study (Wang, 2018) which states that individuals who live a monotonous and routine life, those who remain incapable in time management in short, are experiencing boredom perception more than others. In the direction of the findings and the literature, physical activity has a positive effect in coping with the perception of leisure boredom.

According to the analysis, results in favor of male participants were determined with regard to the gender variable whereas a significant difference was not observed with regard to the participation in physical activity in all sub-dimensions of SSS. It was stated in the literature that the sensation-seeking rates of male participants were higher than female participants (Cross, Cyrenne \& Brown, 2013; Öngen, 2007; Zuckerman, 1994). However, Minkwitz et al., (2016) found no significant difference between the sensation seeking and participation in physical activity in their research. Within the framework of the findings, the need for more complex feelings and experiences varies according to participation in physical activity in male participants.

In the study, results toward determining the relationship among the Internet addition, perceived freedom in leisure time, boredom perception in leisure time and sensation seeking were examined. When the findings were evaluated in general, negative relationships were determined between Internet addiction and perceived freedom and sensation seeking; negative relationships were determined between sensation seeking and boredom perception. According to the findings, Internet addiction is in the inverse connection with freedom perception and the tendency to seek and find new and intense experiences, which is contrary to popular assumptions. However, motivation in existing leisure time activities (not experiencing boredom perception) is seen as an important point for individuals to try new experiences or to focus on the experience that is tried. In coping with 
boredom perception, the importance of stimulation of sensation seeking feelings is seen.

In conclusion, it is suggested by this study that university administrations and governments should support lowering Internet addiction which is thought to be socialization and psychosocial issue for the $\mathrm{Z}$ generation to the minimal level through physical activity and recreational programs in the campus. At this stage, it is obvious that the collaboration of governments and many organizations to solve this problem is an important point. For example, there are many projects on Internet addiction healing and prevention in the Netherlands (Van Rooij, Schoenmakers, \& Mheen, 2012). At this point, the importance of similar improvement projects for Turkish youth is presented with findings.

Considering the limitations of the study, it is suggested for future studies that the examination (longitudinal research) of the effect of the mental health works that are healing and protective in coping with the boredom perception in leisure time in the campus should be performed as well as reaching a broader sample group. However, stating the importance of leisure time activities for university students who build the future world is seen as a golden key to the growth of healthy generations.

\section{References}

Agyar, E. (2013). Life satisfaction, perceived freedom in leisure and self-esteem: The case of physical education and sport students. Procedia-Social and Behavioral Sciences, 93, 2186-2193. https://doi.org/10.1016/j.sbspro.2013.10.185

Al Otaibi, K. N. (2012). Attitudes towards the Use of the Internet. Psychology Research, 2(3), 151-159.

Al-Gamal, E., Alzayyat, A., \& Ahmad, M. M. (2016). Prevalence of internet addiction and its association with psychological distress and coping strategies among university students in Jordan. Perspectives in psychiatric care, 52(1), 49-61. https://doi.org/10.1111/ppc.12102

Andreassen, C. S., Pallesen, S., \& Griffiths, M. D. (2017). The relationship between addictive use of social media, narcissism, and self-esteem: Findings from a large national survey. Addictive Behaviors, 64, 287-293. https://doi.org/10.1016/j.addbeh.2016.03.006

Arısoy, Ö. (2009). Internet Addiction and Its Treatment. Current Approaches in Psychiatry, 1(1), 55. Retrieved from http://www.cappsy.org/archives/vol1/

Barnett, L. A., \& Klitzing, S. W. (2006). Boredom in free time: Relationships with personality, affect, and motivation for different gender, racial and ethnic student groups. Leisure Sciences, 28(3), 223-244. https://doi.org/10.1080/01490400600598053

Blais, J. J., Craig, W. M., Pepler, D., \& Connolly, J. (2008). Adolescents online: The importance of Internet activity choices to salient relationships. Journal of youth and adolescence, 37(5), 522-536. https://doi.org/10.1007/s10964-007-9262-7

Carbonell, X., Chamarro, A., Griffiths, M., Oberst, U., Cladellas, R., \& Talarn, A. (2012). Problematic Internet and cell phone use in Spanish teenagers and young students. Anales de Psicología/Annals of Psychology, 28(3), 789-796. https://dx.doi.org/10.6018/analesps.28.3.156061

Chou, C., Condron, L., \& Belland, J. C. (2005). A review of the research on Internet addiction. Educational Psychology Review, 17(4), 363-388. https://doi.org/10.1007/s10648-005-8138-1

Cross, C. P., Cyrenne, D. M., \& Brown, G. R. (2013). Sex Differences in Sensation-Seeking: A Meta-Analysis. Sclenttfic Reports, 3, 2486. https://doi.org/10.1038/srep02486

Csikszentmihalyi, M. (1975). Beyond Boredom and Anxiety. Experiencing Flow in Work and Play. San Francisco: Jossey-Bass.

Dalbudak, E., Evren, C., Aldemir, S., Taymur, I., Evren, B., \& Topcu, M. (2015). The impact of sensation seeking on the relationship between attention deficit/hyperactivity symptoms and severity of Internet addiction risk. Psychiatry Research, 228(1), 156-161. https://doi.org/10.1016/j.psychres.2015.04.035

Dang, A. K., Nathan, N., Le, Q. N. H., Nguyen, L. H., Nguyen, H. L. T., Nguyen, C. T., ... Tran, B. X. (2018). Associations between internet addiction and physical activity among Vietnamese youths and adolescents. Children and Youth Services Review, 93, 36-40. https://doi.org/10.1016/j.childyouth.2018.06.030

Deal, L. (2005). The Boredom Solution: Understanding and Dealing with Boredom. Prufrock Press Inc.

Ellis, G. D., \& Witt, P. A. (1994). Perceived freedom in leisure and satisfaction: Exploring the factor structure of the perceived freedom components of the leisure diagnostic battery. Leisure Sciences, 16(4), 259-270. 
Ellis, G., \& Witt, P. A. (1984). The measurement of perceived freedom in leisure. Journal of leisure research, 16(2), 110-123. https://doi.org/10.1080/00222216.1984.11969579

Frangos, C. C., Fragkos, K. C., \& Kiohos, A. (2010). Internet Addiction among Greek University Students: Demographic Associations with the Phenomenon, Using the Greek Version of Young's Internet Addiction Test. International Journal of Economic Sciences and Applied Research, 3(1), 49-74. Retrieved from http://hdl.handle.net/10419/66631

Geck, C. (2007). The generation $Z$ connection: Teaching information literacy to the newest net generation. Toward a 21st-Century School Library Media Program, 235.

Haller, M., Hadler, M., \& Kaup, G. (2013). Leisure time in modern societies: A new source of boredom and stress?. Social indicators research, 111(2), 403-434. https://doi.org/10.1007/s11205-012-0023-y

Hawi, N. S., \& Samaha, M. (2017). Relationships among smartphone addiction, anxiety, and family relations. Behaviour \& Information Technology, 36(10), 1046-1052. https://doi.org/10.1080/0144929X.2017.1336254

Hawi, N., \& Samaha, M. (2018). Identifying commonalities and differences in personality characteristics of Internet and social media addiction profiles: traits, self-esteem, and self-construal. Behaviour \& Information Technology, 38(2), 1-10. https://doi.org/10.1080/0144929X.2018.1515984

Hill, A. B., \& Perkins, R. E. (1985). Towards a model of boredom. British Journal of Psychology, 76(2), 235-240. https://doi.org/10.1111/j.2044-8295.1985.tb01947.x

Iso-Ahola, S. E., \& Weissinger, E. (1990). Perceptions of boredom in leisure: Conceptualization, reliability and validity of the leisure boredom scale. Journal of Leisure Research, 22(1), 1-17. https://doi.org/10.1080/00222216.1990.11969811

Jang, S. M., Sohn, S., \& Yu, M. (2018). Perceived stress, alcohol consumption, and Internet use among Korean college students: Does sensation-seeking matter?. Children and Youth Services Review, 88, 354-360. https://doi.org/10.1016/j.childyouth.2018.01.038

Jeroen, S. L., Patti, M. V., \& Jochen, P. (2009). Development and Validation of a Game Addiction Scale for Adolescents, Media Psychology, 12(1), 77-95, https://doi.org/10.1080/15213260802669458

Jones, S., Johnson-Yale, C., Millermaier, S., \& Pérez, F. S. (2009). US college students' Internet use: Race, gender and digital divides. Journal of Computer-Mediated Communication, 14(2), 244-264. https://doi.org/10.1111/j.1083-6101.2009.01439.x

Kang, J., Park, H., Park, T., \& Park, J. (2012). Path analysis for attachment, internet addiction, and interpersonal competence of college students. Kim T, Mohammed S, Ramos C, Abawajy J, Kang BH, Slezak D (editors). New York: Springer.

Kara, F. M., Gürbüz, B., \& Öncü, E. (2014). Leisure Boredom Scale: The factor structure and the demographic differences. The Turkish Journal of Sport and Exercise, 16(2), 28-35. https://doi.org/10.15314/TJSE.201428102

Kara, F. M., Gürbüz, B., Küçük-Kılıç, S., \& Öncü, E. (2018b). An ınvestigation of pre-service physical education teachers' leisure boredom, life satisfaction and social connectedness. Journal of Computer and Education Research, 6(12), 342-357. https://doi.org/10.18009/jcer.466740

Kara, F. M., Gürbüz, B., \& Sarol, H. (2018a). An investigation of adult's leisure boredom, percieved social competence and self-esteem levels. International Journal of Sports, Exercise and Training Science, 4(4), 113-121. https://doi.org/10.18826/useeabd.473994

Khan, M. A., Shabbir, F., \& Rajput, T. A. (2017). Effect of gender and physical activity on Internet addiction in medical students. Pakistan journal of medical sciences, 33(1), 191. https://doi.org/10.12669/pjms.331.11222

Ko, C. H., Yen, J. Y., Yen, C. F., Chen, C. S., \& Chen, C. C. (2012). The association between Internet addiction and psychiatric disorder: a review of the literature. European Psychiatry, 27(1), 1-8. https://doi.org/10.1016/j.eurpsy.2010.04.011

Koca, C. (2016). Cinsiyetlendirilmiş bir sosyal alan olarak spor [Sports as a gendered social space]. (C. Koca, Ed.) Sporun Toplumsal Cinsiyet Halleri [Gender Issues of Sport] (1n Turkish). s. 18-37. Ankara: Spor Yayınevi. 
Kuss, D. J., \& Griffiths, M. D. (2011). Online social networking and addiction—a review of the psychological literature. International journal of environmental research and public health, 8(9), 3528-3552. https://doi.org/10.3390/ijerph8093528

Kutlu, M., Savc1, M., Demir, Y., \& Aysan, F. (2016). Turkish adaptation of Young's Internet Addiction Test-Short Form: a reliability and validity study on university students and adolescents. Anatolian Journal of Psychiatry, 17(Suppl1), 69-76. https://doi.org/10.5455/apd.190501

Lavin, M., Marvin, K., Mclarney, A., Nola, V., \& Scott, L. (1999). Sensation seeking and collegiate vulnerability to Internet dependence. CyberPsychology \& Behavior, 2(5), 425-430. https://doi.org/10.1089/cpb.1999.2.425

Li, W., O’Brien, J. E., Snyder, S. M., \& Howard, M. O. (2015). Characteristics of internet addiction/pathological internet use in US university students: a qualitative-method investigation. PloS one, 10(2), e0117372. https://doi.org/10.1371/journal.pone.0117372

Mazzoni, E., Cannata, D., \& Baiocco, L. (2017). Focused, not lost: The mediating role of temporal dissociation and focused immersion on problematic internet use. Behaviour \& Information Technology, 36(1), 11-20. https://doi.org/10.1080/0144929X.2016.1159249

Minkwitz, J., Chittka, T., Schuster, S., Kirkby, K. C., Sander, C., Hegerl, U., \& Himmerich, H. (2016). Sensation seeking and physical activity. Health Behavior and Policy Review, 3(6), 528-534. https://doi.org/10.14485/HBPR.3.6.2

Mo, P. K., Chan, V. W., Chan, S. W., \& Lau, J. T. (2018). The role of social support on emotion dysregulation and Internet addiction among Chinese adolescents: A structural equation model. Addictive behaviors, 82, 86-93. https://doi.org/10.1016/j.addbeh.2018.01.027

Moreno, M. A., Jelenchick, L., Cox, E., Young, H., \& Christakis, D. A. (2011). Problematic internet use among US youth: a systematic review. Archives of pediatrics \& adolescent medicine, 165(9), 797-805. https://doi.org/10.1001/archpediatrics.2011.58

Müller, K. W., Glaesmer, H., Brähler, E., Woelfling, K., \& Beutel, M. E. (2014). Prevalence of internet addiction in the general population: results from a German population-based survey. Behaviour \& Information Technology, 33(7), 757-766. https://doi.org/10.1080/0144929X.2013.810778

Öngen, D. (2007). The Relationship Between Sensation Seeking and Gender Role Orientation Among Turkish University Students. Sex Roles, 57, 111-118. https://doi.org/10.1007/s11199-007-9214-4

Pawlikowski, M., Altstötter-Gleich, C., \& Brand, M. (2013). Validation and psychometric properties of a short version of Young's Internet Addiction Test. Computers in Human Behavior, 29(3), 1212-1223. https://doi.org/10.1016/j.chb.2012.10.014

Pellegrini, A. D., \& Smith, P. K. (1998). Physical activity play: The nature and function of a neglected aspect of play. Child development, 69(3), 577-598. https://doi.org/10.1111/j.1467-8624.1998.tb06226.x

Phanasathit, M., Manwong, M., Hanprathet, N., Khumsri, J., \& Yingyeun, R. (2015). Validation of the Thai version of Bergen Facebook Addiction Scale (Thai-BFAS). Journal of the Medical Association of Thailand, 98(Supp2), 108-117.

Seyrek, S., Cop, E., Sinir, H., Ugurlu, M., \& Şenel, S. (2017). Factors associated with Internet addiction: Cross-sectional study of Turkish adolescents. Pediatrics international, 59(2), 218-222. https://doi.org/10.1111/ped.13117

Sherrill, C. (1998). Adapted physical activity, recreation and sport: Cross disciplinary and life span. WCB/McGraw Hill, 2460 Kerper Blvd., Dubuque, IA 52001.

Skues, J., Williams, B., Oldmeadow, J., \& Wise, L. (2016). The effects of boredom, loneliness, and distress tolerance on problem internet use among university students. International Journal of Mental Health and Addiction, 14(2), 167-180. https://doi.org/10.1007/s11469-015-9568-8

Sommers, J., \& Vodanovich, S. J. (2000). Boredom proneness: Its relationship to psychological-and physical-health symptoms. Journal of clinical psychology, 56(1), 149-155. https://doi.org/10.1002/(SICI)1097-4679(200001)56:1<149::AID-JCLP14>3.0.CO;2-Y

Spruyt, B., Vandenbossche, L., Keppens, G., Siongers, J., \& Van Droogenbroeck, F. (2018). Social Differences in Leisure Boredom and its Consequences for Life Satisfaction Among Young People. Child Indicators Research, 11(1), 225-243. https://doi.org/10.1007/s12187-016-9430-y 
Stavropoulos, V., Griffiths, M. D., Burleigh, T. L., Kuss, D. J., Doh, Y. Y., \& Gomez, R. (2018). Flow on the Internet: A longitudinal study of Internet addiction symptoms during adolescence. Behaviour \& Information Technology, 37(2), 159-172. https://doi.org/10.1080/0144929X.2018.1424937

van Rooij, A. J., Schoenmakers, T. M., Van den Eijnden, R. J., Vermulst, A. A., \& van de Mheen, D. (2012). Video game addiction test: validity and psychometric characteristics. Cyberpsychology, Behavior, and Social Networking, 15(9), 507-511. https://doi.org/10.1089/cyber.2012.0007

Vodanovich, S. J., \& Watt, J. D. (2016). Self-report measures of boredom: An updated review of the literature. The Journal of Psychology, 150(2), 196-228. https://doi.org/10.1080/00223980.2015.1074531

Wang, C. -W., Ho, R., Chan, C., \& Tse, S. (2015). Exploring personality characteristics of Chinese adolescents with internet-related addictive behaviors: Trait differences for gaming addiction and social networking addiction. Addictive Behaviors, 42, 32-35. https://doi.org/10.1016/j.addbeh.2014.10.039

Wang, W. C. (2018). Exploring the Relationship Among Free-Time Management, Leisure Boredom, and Internet Addiction in Undergraduates in Taiwan. Psychological reports. https://doi.org/0033294118789034.

Warbrick, I., Wilson, D., \& Boulton, A. (2016). Provider, father, and bro-Sedentary Māori men and their thoughts on physical activity. International journal for equity in health, 15(1), 22. https://doi.org/10.1186/s12939-016-0313-0

Whang, L. S. M., Lee, S., \& Chang, G. (2003). Internet over-users' psychological profiles: A behavior sampling analysis on internet addiction. CyberPsychology \& Behavior, 6, 143-151. https://doi.org/10.1089/109493103321640338

Yerlisu, L. T., \& Tercan, K. E. (2017). Perceived Freedom in Leisure Scale: Testing The Construct Validity. World Congress of Sport Sciences Researches, Manisa, Turkey, 23-26 November, pp.216-217

Young, K. S. (1998). Internet addiction: The emergence of a new clinical disorder. Cyberpsychology \& behavior, l(3), 237-244. https://doi.org/10.1089/cpb.1998.1.237

Zuckerman, M. (1994). Behavioral Expressions and Biosocial Bases of Sensation Seeking. New York: Cambridge University Press.

Zuckerman, M. (1996). The psychobiological model for impulsive unsocialized sensation seeking: a comparative approach. Neuropsychobiology, 14, 125-129. http://dx.doi.org/10.1159/000119303

Zuckerman, M. (2007). Sensation Seeking and Substance Use and Abuse: Smoking, Drinking, and Drugs. In M. Zuckerman, Sensation seeking and risky behavior (pp. 107-143). Washington, DC, US: American Psychological Association. http://dx.doi.org/10.1037/11555-004

Zuckerman, M., Eysenck, S. B., \& Eysenck, H. J. (1978). Sensation seeking in England and America: Cross-cultural, age, and sex comparisons. Journal of Consulting and Clinical Psychology, 46(1), 139-149. http://dx.doi.org/10.1037/0022-006X.46.1.139

\section{Copyrights}

Copyright for this article is retained by the author(s), with first publication rights granted to the journal.

This is an open-access article distributed under the terms and conditions of the Creative Commons Attribution license (http://creativecommons.org/licenses/by/4.0/). 